\title{
Pattern and Variation of C:N:P Ratios in China's Soils: A Synthesis of Observational Data
}

Hanqin Tian ${ }^{1}$, Guangsheng Chen ${ }^{1}$, Chi Zhang ${ }^{1}$, Jerry M. Melillo ${ }^{2}$ and Charles A.S. Hall $^{3}$

${ }^{1}$ Ecosystem Dynamics and Global Ecology Laboratory, School of Forestry and Wildlife Science, Auburn University, AL 36849, USA; ${ }^{2}$ The Ecosystems Center, Marine Biological Laboratory, Woods Hole, MA 02543, USA; and ${ }^{3}$ College of Environmental Science \& Forestry, State University of New York, Syracuse, NY 13210, USA

${ }^{1}$ Correspondence:

Hanqin Tian

School of Forestry and Wildlife Science, Auburn University, AL36849, USA

Email: tianhan@auburn.edu

Phone: 334-844-1059

Fax: 334-844-1084 
1 Abstract Inspired by previous studies that have indicated consistent or even

2 well-constrained relationships among carbon $(\mathrm{C})$, nitrogen $(\mathrm{N})$ and phosphorus $(\mathrm{P})$ in

3 soils, we have endeavored to explore general soil C:N:P ratios in China on a national

4 scale, as well as the changing patterns of these ratios with soil depth, developmental

5 stages and climate; we also attempted to determine if well-constrained C:N:P

6 stoichiometrical ratios exist in China's soil. Based on an inventory data set of 2,384

7 soil profiles, our analysis indicated that the mean $\mathrm{C}: \mathrm{N}, \mathrm{C}: \mathrm{P}$ and $\mathrm{N}: \mathrm{P}$ ratios for the entire

8 soil depth (as deep as $250 \mathrm{~cm}$ for some soil profiles) in China were 11.9, 61 and 5.2,

9 respectively, showing a $\mathrm{C}: \mathrm{N}: \mathrm{P}$ ratio of $\sim 60: 5: 1$. C:N ratios showed relatively small

10 variation among different climatic zones, soil orders, soil depth and weathering stages,

11 while $\mathrm{C}: \mathrm{P}$ and $\mathrm{N}: \mathrm{P}$ ratios showed a high spatial heterogeneity and large variations in

12 different climatic zones, soil orders, soil depth and weathering stages. No

13 well-constrained C:N:P ratios were found for the entire soil depth in China. However,

14 for the $0-10 \mathrm{~cm}$ organic-rich soil, where has the most active organism-environment

15 interaction, we found a well-constrained $\mathrm{C}: \mathrm{N}$ ratio (14.4, molar ratio) and relatively

16 consistent C:P (136) and N:P (9.3) ratios, with a general C:N:P ratio of 134:9:1.

17 Finally, we suggested that soil C:N, C:P and N:P ratios in organic-rich topsoil could be

18 a good indicator of soil nutrient status during soil development.

19

20 Keywords Carbon $\cdot$ Nitrogen $\cdot$ Phosphorus $\cdot$ Stoichiometry $\cdot$ China 


\section{Introduction}

All substances on earth are composed of chemical elements, and elemental composition is the most fundamental in biology and ecology (Michaels 2003; Schimel 2003). Thus a cell, an organism, an ecosystem, and even the biosphere can be reduced to its elemental composition in some simple elemental ratios. Although soil is influenced by complex factors such as climate, soil parent materials, topography and development stages, and is often characterized by high biological diversity, structural complexity and spatial heterogeneity (Chadwick et al. 1999; Cleveland and Liptzin 2007), many previous studies (e.g. Melillo et al. 2003; Vitousek et al. 2002, 2004; Brady and Weil 2002; Post et al. 1982; Walker and Adams 1958) have indicated that soil carbon $(\mathrm{C})$, nitrogen $(\mathrm{N})$ and phosphorus $(\mathrm{P})$ are often closely related. Walker (1956) suggested that $\mathrm{C}, \mathrm{N}$, and $\mathrm{P}$ are associated in fairly definite proportions in soil organic matter (SOM). Based on the analysis of 22 grassland soil profiles, Walker and Adams (1958) found a constrained correlation among organic C (SOC) and organic P (SOP) in the soil. Through a literature review of 48 published resources, Cleveland and Liptzin (2007) found a well constrained C:N:P ratio in global soil microbial biomass and $0-10 \mathrm{~cm}$ organic-rich soil. All these findings reported relatively constrained elemental ratios, or homeostasis, in plants and soil organisms. It is suggested that the feedbacks from living organisms can modify soil nutrient content and result in "Redfield-like" correlations between the elemental ratio of the biota and soil in terrestrial ecosystems (Neff et al. 2000; Stener and Elser 2002; Cleveland and Liptzin 
2007).

Redfield (1958) found that planktonic biomass contains C, N and P in an atomic ratio of 106:16:1, similar to the ratio of $\mathrm{C}, \mathrm{N}$ and $\mathrm{P}$ in marine water. This $\mathrm{C}: \mathrm{N}: \mathrm{P}$ ratio, known as "Redfield Ratio", has stimulated a large number of subsequent studies on the $\mathrm{C}: \mathrm{N}: \mathrm{P}$ stoichiometry of multiple biota in aquatic and terrestrial ecosystems (e.g., Sterner 1995; Elser et al. 1996; Stener and Elser 2002; Cleveland and Liptzin 2007; McGroddy et al. 2004). Compared to marine ecosystems, terrestrial ecosystems vary greatly due to varied and complex habitats, biota and environmental factors.

Furthermore, soil is far more complex than other terrestrial systems. The relative immobility of the soil tends to promote and maintain spatial heterogeneity in nutrient cycles. This heterogeneity is caused by both local-scale disturbances, such as land use change and human interferences, and regional-scale differences in glacial history, climate, geologic parent material, topography, and biotic diversity (Jenny 1941).

Nutrients are continuously redistributed in terrestrial ecosystems by a number of ways including plant litterfall, soil water flow and plant-atmosphere exchange, none of which appears within marine environments (McGroddy et al. 2004). Unlike the homogeneous aquatic environment, soil is highly heterogeneous both horizontally and vertically. The soil P supply depends on the total P content and the weathering stage of the parent material, both of which are characterized by spatial heterogeneities.

Furthermore, the infiltration and diffusion rate of nutrients in soil is much slower than

in the aquatic ecosystem. As the result, the feedbacks from terrestrial organisms are

65 limited to the top-soil, while the supply of $\mathrm{P}$ comes from the parent materials that are 
located at the bottom of the soil. This mechanism results in a complex and highly variable vertical pattern of total $\mathrm{P}(\mathrm{TP})$ content through the soil profile (Brady and Weil 2002). Based on vertical soil analysis to a depth of $53 \mathrm{~cm}$, Walker and Adams (1958) concluded that the total soil P content was related to the P content of parent material, and decreased down through the soil profile at a rate much slower than the rate of $\mathrm{C}$ and $\mathrm{N}$. This finding indicates that soil has inconsistent vertical patterns of N:P ratio. Although Cleveland and Liptzin (2007) stated that a remarkably constrained soil C:N:P ratio of 186:13:1 exists on the global scale, their analysis was mainly based on samples from surface soils $(0 \sim 10 \mathrm{~cm}$ mineral soil). The constrained $\mathrm{C}: \mathrm{N}: \mathrm{P}$ ratio in the topsoil found by Cleveland and Liptzin (2007) may not be applicable to the entire depth of soil profiles.

Considering the high spatial heterogeneity of soil nutrients and the dependence of P supply on weathering conditions of parent material, large-scale soil datasets of soil C, $\mathrm{N}$, and $\mathrm{P}$ that cover a range of ecosystem types and soil weathering stages are necessary to examine the patterns of elemental ratio in the soil. However, even the most frequently cited global soil database today, the World Inventory of Soil Emission (WISE) database (Batjes 2002), contains less than 900 soil profiles that record soil P content. While several previous studies tried to compile soil observations through published reports, inconsistent soil sampling and measuring approaches, as well as incomplete site descriptions from various literature resources has usually limited the quantity and quality of available data sources.

Since China has various soil types that developed under different bioclimatic 


9

conditions and are derived from various parent materials in diversified topographical environments, the study of the relationships among $\mathrm{C}, \mathrm{N}$, and $\mathrm{P}$ in China's soil is likely to make great contributions to the establishment of a global $\mathrm{C}, \mathrm{N}$, and P relationship. Based on soil chemical data from the Second Chinese Soil Survey, which provided $\mathrm{C}: \mathrm{N}: \mathrm{P}$ for over 2,473 typical soil profiles across China that were sampled and measured in standard approaches (Wang, et al. 2003; Tian, et al. 2006; Zhang, et al. 2005; Wu et al. 2003; Yang et al. 2007), our objectives in this study are to: 1) explore the general C:N, C:P and N:P ratios in China's soil at a national scale; and 2) find how these ratios change with climate, soil orders, soil depth and weathering status. Based on these two objectives, we have also tried to verify whether or not well-constrained $\mathrm{C}: \mathrm{N}: \mathrm{P}$ ratios exist in the top and deeper soils.

\section{Materials and methods}

Data sources

We examined geo-referenced soil profiles collected in the second Chinese soil survey and developed mean values for various soil groups (National Soil Survey Office 1993, 1994a, b, 1995a, b, 1996). This database includes 2,473 soil profiles, each of which represents a soil type in the Chinese Soil Taxonomy system (Li and Zhao 2001; Wang et al 2003). Each soil profile is divided into A, B, C and other horizons, according to actual soil conditions. The properties investigated include the thickness of horizons, 
110

111

112 colorimetric test), total soil N (analyzed with the Kjeldahl procedure), soil bulk density

113 (measured according to the core sampling method), soil available P (The Olsen method

114 (Olsen et al., 1954) was used for available P analysis) and geographic location

115 information. SOC content was calculated as a portion of SOM which has been

116 described by Wang et al. (2003). Of all the 2,473 soil profiles, 2,405 have total $\mathrm{P}$

117 content records, 2,462 have SOM data and 2,445 have total $\mathrm{N}$ records, 1,760 have

118 available $\mathrm{P}$ records, and 1,535 profiles have geographic location information. We

119 excluded soil profiles that did not have any of the total $\mathrm{C}, \mathrm{N}$ or $\mathrm{P}$ data. The final dataset

120 used in this analysis includes 2,384 soil profiles. We integrated the soil data for the

$121 \quad 1,535$ profiles for which we had geographical information into a Geographical

122 Information System (GIS) database to show their geographic distribution (Fig. 1).

123

124 used in this soil survey. This system has a hierarchical structure, with 12 orders, 61

125 great groups, 235 sub-great groups, 909 families and more than 2,473 soil types (soil

126 profiles, each with its distribution area in China). Using the transformation procedure

127 of Zhang et al. (2005), we were able to compare these results with the United Nation

128 Food and Agriculture Organization/UNESCO (1988) soil classification system, and

129 also the equivalent USDA soil taxonomy system (Soil Survey Staff 1975).

130 Calculation of soil $\mathrm{C}, \mathrm{N}$ and $\mathrm{P}$ ratios: The soil total $\mathrm{C}, \mathrm{N}$ and $\mathrm{P}$ concentrations

$131(\mathrm{mg} / \mathrm{kg})$ were transformed to a unit of $\mathrm{mmol} / \mathrm{kg}$, and $\mathrm{C}: \mathrm{N}, \mathrm{C}: \mathrm{P}$ and $\mathrm{N}: \mathrm{P}$ ratios for each 
132 type soil were calculated as molar ratios (atomic ratio), rather than mass ratios. To

133 reflect China's soil $\mathrm{C}, \mathrm{N}$ and $\mathrm{P}$ ratios more accurately, we used both area-weighted and

134 number-weighted average methods to calculate the mean ratios. The formula for

135 area-weighted mean soil $\mathrm{C}, \mathrm{N}$ and $\mathrm{P}$ ratios is:

136

$$
\bar{R}_{C N P}=\frac{\sum_{i=1}^{n}\left(A R E A_{i} \times R_{C N P i}\right)}{\sum_{i=1}^{n} A R E A_{i}},
$$

137 where $\bar{R}_{C N P}$ is the area-averaged C: N, C: P or N: P ratio, $i$ refers to the $i^{\text {th }}$ soil

138 type; $n$ is the total number of soil, $A R E A_{i}$ is the area of the $i^{\text {th }}$ soil type, and $R_{C N P i}$ is

139 the corresponding C: N, C: P or N: P ratio of the $i^{\text {th }}$ soil type. The number-weighted

140 average also has its own advantages as the impacts of soil area on soil C, N and P ratio

141 patterns can be discerned and results from different research studies can be compared.

142 Therefore, we calculated mean C, N and P ratios for different soil orders, soil depth

143 and climate zones using number-weighted average. The formula for a

144 number-weighted average is:

$$
\bar{R}_{C N P}=\frac{\sum_{i=1}^{n}\left(R_{C N P i}\right)}{n}
$$

146 Because the classification systems of soil horizons are different for different soil

147 samples, we divided each soil profile into four layers with a range of soil depths (0-10

$148 \mathrm{~cm}, 20-50 \mathrm{~cm}, 50-100 \mathrm{~cm}$, and $>100 \mathrm{~cm}$, respectively), rather than into the horizontal

149 or subhorizontal types (such as $\mathrm{O}, \mathrm{A}, \mathrm{E}, \mathrm{B}$ and $\mathrm{C}$ horizons). The patterns of soil C, N

150 and $\mathrm{P}$ concentrations and their ratios for these four layers were compared in all soil

151 types and orders. We calculated the C: N, C: P and N: P ratios of each soil layer using 
152 the soil $\mathrm{C}, \mathrm{N}$ and $\mathrm{P}$ concentration data of the corresponding soil type and layer. The

153 mean $\mathrm{C}, \mathrm{N}$ and $\mathrm{P}$ concentrations and $\mathrm{C}: \mathrm{N}, \mathrm{C}: \mathrm{P}$ and $\mathrm{N}: \mathrm{P}$ ratios of each soil layer were

154 based on number-weighted averages (Formula 2). The mean C: N, C: P and N: P

155 ratios for all Chinese soil types (entire depth) were based on the number-averaged

156 values of all the soil types (Formula 2) rather than on soil sub-great groups or soil

157 orders.

158 We changed the Chinese soil taxonomic classification system to produce 12 soil

159 orders (Entisols, Gelisols, Histosols, Inceptisols, Andisols, Aridisols, Vertisols, Alfisols,

160 Mollisols, Ultisols, Spodosol, and Oxisols) which correspond to the USDA soil

161 taxonomic system (Zhang et al. 2005). We then compared the $\mathrm{C}, \mathrm{N}$ and $\mathrm{P}$

162 concentrations and ratios of different soil orders. The $\mathrm{C}, \mathrm{N}$ and $\mathrm{P}$ concentrations and

163 ratios of each soil sub-great group were averaged based on Formula 2. We

164 reclassified these 12 soil orders into three soil weathering status groups: slightly

165 weathered soils (Entisols, Gelisols, Inceptisols,), moderately weathered soils (Aridisols,

166 Vertisols, Alfisols, Mollisols), and strongly weathered soils (Ultisols, Spodosol,

167 Oxisols) according to the soil developmental time series described by Brady and Weil

168 (2002) and Zhang et al. (2005). We compared the C, N and P ratios of these three

169 weathering status groups based on data that considered entire soil depth.

170

171 Division of climate zones

172 
173 Precipitation and temperature are known to influence vegetative cover, plant litter

174 quality and soil biota, which in turn influence the physical and chemical properties of

175 soil, and soil development. Thus, climate can leave a distinct imprint on soil C, N,

176 and $\mathrm{P}$ concentrations and ratios. China is characterized by great spatial variability in

177 climate, ranging from tropical to cool temperate zones (Tian et al., 2003; Wu et al.,

178 2003). The tropical \& subtropical zone is extremely humid due to the influence of

179 Asian monsoon circulations (Tian et al., 2003), while in frigid highland areas annual

180 precipitation and temperature are very low due to the northern location and higher

181 elevation (See Table 1). Considering the obvious differences in climate and parent

182 soil types, and applying the Holdridge life-zone classification system, we divided

183 China into five zones: frigid highland, cool temperate, warm temperate, temperate

184 desert, and tropical \& subtropical, based on the 1: 1,000,000 Land-use Map of China

185 (Wu 1988). These five zones reflect only climate differences among these zones,

186 rather than any specific land covers. For example, Temperate Desert includes

187 woodlands, grasslands, desert, wetlands, and other types of land cover. We obtained

188 the mean soil C, $\mathrm{N}$ and $\mathrm{P}$ concentrations and ratios in each climate zone by averaging

189 the corresponding values of all soil types within the climate zone (Formula 2).

190 Statistical Analysis

191 We performed all the statistic analyses using SPSS v11.5 software (SPSS Inc.,

192 Chicago, Illinois). We used variance of analysis (ANOVA) with LSD (Least Square

193 Difference) post hoc test of significance to compare C, N and P concentrations,

194 densities, and ratios within and across groups. The mean values were reported with 
195

196

197 Results and analysis

198

199 General patterns of soil C, N and $\mathrm{P}$ ratios in China

201 Although soil C, N and P content varied significantly due to the differences in climate, 202 parent material, biota, topography and disturbance history, we found a general pattern

203 of soil $\mathrm{C}, \mathrm{N}$ and $\mathrm{P}$ ratios in China (Table 2). The number-weighted mean soil $\mathrm{C}$ : N, C:

204 P and N: P ratios were 11.9, 61 and 5.2, respectively, which was not vastly different 205 from area-weighted means $(12.1,61$, and 5.0, respectively, Table 2). The C: N, C: P 206 and N: P ratios of the surface organic-rich layer (0-10 $\mathrm{cm}$ of A horizon) were 14.4, 136, 207 and 9.3, respectively. From the frequency distribution of soil C, N and P ratios (Fig. 2), 208 we found that all the soil elemental ratios followed a normal distribution pattern, with 209 most C:N, C:P and N:P ratios in the range of 6-12, 24-48, and 3-6, respectively.

210 The C:N, C:P and N:P ratios of the organic-rich soil layer were significantly

211 higher than corresponding values for total soil depth (Table 2). The C:N:P ratio

212 (134:9:1) of this layer was also different from that of the total soil depth $(60: 5: 1)$.

213 However, the $\mathrm{C}$ : available $\mathrm{P}(15,810)$ and $\mathrm{N}$ : available $\mathrm{P}(1114)$ ratios of the

214 organic-rich layer were significantly lower than that of the total soil depth $(64,233$ and 2155,725 , respectively).

216 The $\mathrm{C}: \mathrm{N}$ ratio showed no significant difference among different soil depths 
217 where the deeper soil was greater than $50 \mathrm{~cm}$ (Table 3). The C: P ratio of the

218 organic-rich soil layer was over four times higher than that of the $>100 \mathrm{~cm}$ soil layer

219 and showed significant decrease as soil depth increased; this can be attributed to soil C

220 concentration decreasing faster than soil P concentration as soil depth increases. The

221 vertical pattern of the $\mathrm{N}: \mathrm{P}$ ratio was similar to that of the $\mathrm{C}: \mathrm{P}$ ratio, showing a peak

222 value in $0-10 \mathrm{~cm}$ organic-rich soil (Table 3 ).

223 The highest C:N ratios were found in Northeast China, the eastern Tibet Plateau

224 and sandy areas of Northwest China(Fig. 3a). The C:P and N:P ratios showed almost

225 the same distribution patterns across China. The highest $\mathrm{C}: \mathrm{P}$ and $\mathrm{N}: \mathrm{P}$ ratios were

226 found in Northeast China and the eastern Tibet Plateau (Fig. 3b, 2c), which might be

227 due to $\mathrm{C}$ and $\mathrm{N}$ having a higher rate of accumulation than P's weathering rate.

229 Soil C, N and P ratios among different climate zones and soil orders

231 The highest $\mathrm{C}: \mathrm{N}$ ratio (13.6) was in the frigid highland zone where there is soil with

232 higher $\mathrm{C}$ content and lower $\mathrm{N}$, while the lowest one (10.7) was in the warm temperate

233 zone which has the lowest $\mathrm{C}$ and $\mathrm{N}$ contents compared to other climate zones. Soil C: $\mathrm{P}$

234 and N: P ratios varied considerably among different climate zones (Table 4). The

235 highest $\mathrm{C}: \mathrm{P}(78)$ and $\mathrm{N}: \mathrm{P}(6.4)$ ratios occurred in the tropical \& subtropical zone which

236 had the lowest $\mathrm{P}$ content, while the lowest $\mathrm{C}: \mathrm{P}(32)$ and $\mathrm{N}: \mathrm{P}$ (2.6) ratios were in the

237 temperate desert zone where $\mathrm{N}$ content was lower and $\mathrm{P}$ content was the greatest.

238 Soil orders are assigned largely on the basis of soil properties that reflect the 
239 course of major soil developments; thus, C, N and P ratios of a specific soil order can

240 reflect the accumulated impact of climate, organisms, relief, parent material, and time

241 on soil chemical properties (Jenny, 1941). In China, only nine soil orders were found,

242 with Histosols and Andisols being the least frequent (Table 5). We found that

243 Histosols had the highest C: N ratio, while Vertisols and Entisols had the lowest.

244 With the exception of Histosols, the differences between $\mathrm{C}: \mathrm{N}$ ratios and the eight

245 remaining soil orders in China were small (variance range from 10.73 to 13.38).

246 Histosols had the highest C: P (340) and N:P ratios (17.77), while Aridisols had the

247 lowest $\mathrm{C}: \mathrm{P}(29.0)$ and $\mathrm{N}: \mathrm{P}(2.60)$ ratios.

\section{Discussions}

251 Do well-constrained soil C:N:P stoichiometric ratios exist?

253 Well-constrained C:N:P ratios in planktonic biomass were found to have important

254 impacts on nutrient cycles and biological processes in marine ecosystems. The

255 "Redfield-like" ratios were found in plants (e.g. Reich and Oleksyn 2004; McGroddy

256 et al. 2004) and soil microbial communities (e.g. Cleveland and Liptzin 2007). Could

257 the relatively fixed elemental ratios in terrestrial organisms (such as plant leaves, litters,

258 and microbes) result in consistent nutrient ratios in the soil just like that found by

259 Redfield (1958) in the marine ecosystem? Could the analysis of soil element ratios

260 provide insight into the nature of nutrient limitation in terrestrial ecosystems? 
261 Cleveland and Liptzin (2007) studied the C:N:P stoichiometry in soil and stated that

262 similar to marine ecosystems, the atomic C:N:P ratios in the top soil were

263 well-constrained due to the interactions between the environment and soil organisms.

264 Their study, however, only focused on surface soils (typically $0-10 \mathrm{~cm}$ ), which

265 represent organic-rich horizons, and their data were obtained from discrete publications.

266 The limited sample size $(<150)$ of their study also indicates that it is necessary for

267 further studies to verify the well-constrained relationships at the top soil.

268 Based on more than 2,437 soil profiles and over 8,000 soil layers across China,

269 we carried out the correlation analyses among soil total C, N and P and among total C,

270 total $\mathrm{N}$ and available $\mathrm{P}$ (Table 9), the results revealed that the $\mathrm{C}: \mathrm{N}$ ratio of the

271 organic-rich soil layer was well-constrained considering the relatively high correlation

272 coefficient (0.93) among $\mathrm{C}$ and $\mathrm{N}$ concentrations. There were also relatively

273 constrained C:P and N:P ratios in the organic-rich soil layer (Correlation coefficients

274 were 0.62 and 0.51 , respectively). This might imply that there has a relatively

275 constrained $\mathrm{C}: \mathrm{N}: \mathrm{P}$ ratio in the organic-rich soil layer as reported by Clevaland and

276 Liptzin (2007). In this sense, we agree with Cleveland and Liptzin (2007) on their

277 statement that "Redfield-like" interactions between C, N and P may exist in soil. We

278 found a similar C:N ratio (14.4) to that found by Clevaland and Liptzin (2007) in the

279 organic-rich soil layer, but we found lower C:P (136) and $\mathrm{N}: \mathrm{P}(9.3)$ ratios; that the

280 C:N:P ratio (134:9:1) from this study is different from theirs (186:13:1) implies that

281 C:N:P ratios might change with environmental factors although $\mathrm{C}, \mathrm{N}$ and $\mathrm{P}$ are

282 relatively well-constrained at the organic-rich topsoil. When came to the total soil 
depth, there was no relatively constrained $\mathrm{C}: \mathrm{N}: \mathrm{P}$ stoichiometric ratios for deeper soil (correlation coefficients are very low except that between total C and N, Table 9). However, a well-constrained $\mathrm{C}: \mathrm{N}$ ratio was found for the deeper soil considering its higher correlation coefficient (0.88). Many previous studies (e.g. Vitousek 2004; Melillo et al. 2003; Post et al. 1985) also found strong correlations between total C and total $\mathrm{N}$ in the soil. As in the marine ecosystem where most of the soil $\mathrm{N}$ is fixed by microorganisms, the relatively constrained $\mathrm{C}: \mathrm{N}: \mathrm{P}$ ratios in the topsoil reflect the ability of terrestrial organisms to modify their abiotic environment to meet their nutrient requirements.

Unlike the soil $\mathrm{C}$ and $\mathrm{N}$, the weathering of the parent material, which is located at the bottom of the soil profile, provides the major sources of available soil P (Walker and Adams 1958). Soil P is further translocated by plants and accumulated in the surface soil in the form of SOP resulting in a complex vertical distribution pattern in the soil profile (Smeck 1985; Mellilo et al. 2003; Vitousek 2004). We found that the C:P ratio decreased dramatically with the soil depth (Table 3). Walker and Adams (1958) also found that as the soil depth increased, the C:P ratio declined much faster than the $\mathrm{C}: \mathrm{N}$ ratio. This is mainly because of the relatively stable soil $\mathrm{P}$ content throughout the soil profile when compared to the rapid decline in SOC with soil depth (Table 3). Through analyses of C: P and N: P ratios, we found that despite large variations of $\mathrm{C}$ and $\mathrm{N}$ content, low soil $\mathrm{P}$ content always led to high $\mathrm{C}: \mathrm{P}$ and $\mathrm{N}: \mathrm{P}$ ratios. This pattern indicates, as suggested by Walker and Adams (1958), that the 
$305 \mathrm{C}: \mathrm{N}: \mathrm{P}$ ratio in the soil is mainly controlled by the $\mathrm{P}$ supply.

306 Although there is no constrained $\mathrm{C}: \mathrm{N}: \mathrm{P}$ ratio in the deeper soil, the vertical

307 distribution of $\mathrm{P}$ in the soil still provided strong evidence of biotic regulation of soil

308 nutrients. Despite the location of the parent material and the downward movement of $\mathrm{P}$

309 leaching, the terrestrial organisms seem to be able to reduce $\mathrm{P}$ gradient along the soil

310 profile by uptake and trans-locating P from the P-rich deep soil to the surface layer to

311 meet their nutrient requirements (Zhang et al. 2005).

312

313 Controlling factors in the C:N:P ratio in China's soil

315 Climate imposes important controls both on soil development and on the biota and its

316 interaction with the soil nutrients (Chadwick et al. 1999; Vitousek 2004; Oleksyn

317 2004). Spatial distribution of soil C, N and P density across China has seen substantial

318 variation (Wang et al. 2003; Zhang et al. 2005; Tian et al. 2005). Despite the spatial

319 variations of $\mathrm{C}$ and $\mathrm{N}$ contents, the $\mathrm{C}: \mathrm{N}$ ratio was relatively stable among climate

320 zones (Table 4), indicating the feedbacks of a similar biota on the chemical

321 composition of the soil. The C:P and N:P ratios, however, varied significantly among

322 different climate zones in China (Table 4). The element ratio highlights the impacts of

323 extreme climate regimes on soil nutrient balance. The high temperature and

324 precipitation in tropical-subtropical regions can result in high $\mathrm{P}$ leaching rate and $\mathrm{P}$

325 occlusion in highly weathered soils (Vitousek and Walker 1987; Neufeldt et al. 2000;

326 Zhang et al. 2005). At the same time, the high productivity of tropical-subtropical 
327 ecosystems maintains relatively high soil $\mathrm{C}$ and $\mathrm{N}$ content, which gave these regions

328 the highest $\mathrm{C}: \mathrm{P}$ and $\mathrm{N}: \mathrm{P}$ ratios. In contrast, the dry and cool climate regime in the

329 temperate desert resulted in low productivity, lower soil $\mathrm{C}$ and $\mathrm{N}$ contents and low $\mathrm{P}$

330 loss through leaching, and higher soil $\mathrm{P}$ content, which gave it the lowest soil C:P and

$331 \quad \mathrm{~N}: P$ ratios among all the climate zones.

332 Site-level chronosequence studies have suggested that soil C:N:P ratios may

333 change during soil development, indicating a shift in soil limitation nutrients (Crews et

334 al. 1995; Chadwick et al. 1999; Frizano et al. 2002; Vitousek 2004). To capture the

335 pattern of elemental ratios of different soil developmental stages, we further grouped

336 the nine soil orders into three soil weathering classes: slight, moderate and strong

337 weathering soil (Brady and Weil 2002; Zhang et al. 2005). The soil C: $\mathrm{N}$ ratios

338 increased significantly $(\mathrm{P}<0.05)$ with increasing soil weathering time $(11.37,12.32$,

339 and 13.32, respectively) (Table 6). We also found that the strongly weathered soil

340 had the highest $\mathrm{C}$ : P ratio (99.0), while the C: P ratio of the moderately weathered soil

341 (63.1) was similar to that of the slight weathering soil (64.9). The N: P ratio showed

342 the same trend, with the highest N: P ratio in strong weathering soil (7.37), indicating $\mathrm{P}$

343 deficiency in highly weathered soils. The N:P ratio was found to be the lowest in the

344 moderate weathering soil (5.41), which was not significantly lower than that of the

345 slight weathering soil (5.78). This result was similar to that reported by Crews et al.

346 (1995) and Vitousek (2004). Walker and Syers (1976) proposed that soil total P

347 decreases with increasing soil developmental time. We found the same pattern in this 348 study. 
350 Chinese vs. global soil C:N:P ratios

351

361 the world (Table 7). The average $\mathrm{C}: \mathrm{N}$ ratio reported by Batjes for all soil orders at

$362 \quad 0-100 \mathrm{~cm}$ depth (14.42) was higher than our corresponding values. Both studies found

363 Histosols had the highest $\mathrm{C}$ : $\mathrm{N}$ ratio. Based on global soil $\mathrm{C}$ and $\mathrm{N}$ data of 2,700 soil

364 profiles from Oak Ridge National Laboratory (http://www.dacc.ornl.gov, Zinke et al.

365 1984), Post et al. (1982; 1985) reported global patterns of soil C and N storage and C:

$366 \mathrm{~N}$ ratios in terms of the Holdridge life zones. We summarized the mass-based C:N

367 ratios and transformed them into mole-based ratios for climate zones: tundra/ Frigid

368 highland (20.3), cool temperate zone (20.2), warm temperate zone (20.6), and tropical

369 and subtropical zone (15.4), respectively. We found that all the C: $\mathrm{N}$ ratios reported by

370 Post et al. were higher than our results for each corresponding climate zone. These 
371 differences might be due to some of the soil samples used in Post et al. (1985) having a

372 humified litter layer (i.e., $0 \mathrm{~cm}$ soil depth in the Zinke et al. 1984 dataset) which has a

373 higher C:N ratio than soil. For regional climate patterns, Post et al. (1985) indicated

374 that relatively large amounts of soil $\mathrm{N}$ in tropical and subtropical regions was

375 associated with both recalcitrant humic materials in an advanced state of decay and the

376 lowest $\mathrm{C}: \mathrm{N}$ ratios, while slow decomposition in boreal regions resulted in higher $\mathrm{C}: \mathrm{N}$

377 ratios than in other regions. Since Post et al.'s research included no soil samples from

378 China, our dataset and analysis can provide valuable supplementary information for the

379 study of global soil C:N ratios. The reports for large-scale soil C:P and N:P ratio

380 patterns are limited. Recently, Cleveland and Liptzin (2007) estimated the global soil

381 C:P and N:P ratios of the surface soil $(0-10 \mathrm{~cm})$ to be 186 and 13.1 , respectively. Our

382 analysis reveals relatively lower C:P (136) and N:P 9.3 ratios at the $0-10 \mathrm{~cm}$ soil in

383 China.

384

385 Conclusions

386 We found that the number-weighted average soil $\mathrm{C}: \mathrm{N}, \mathrm{C}: \mathrm{P}$, and $\mathrm{N}: \mathrm{P}$ ratios in

387 China were 12, 61, and 5, respectively, with a C: N: P ratio of 60:5:1 for all soil layers.

388 The $\mathrm{C}: \mathrm{N}$ ratio variation range among samples from different climate zones and

389 different soil depth was relatively small, while large spatial heterogeneity (both

390 horizontal and vertical) was found in $\mathrm{C}: \mathrm{P}$ and $\mathrm{N}: \mathrm{P}$ ratios. $\mathrm{C}: \mathrm{P}$ and $\mathrm{N}: \mathrm{P}$ ratios decreased

391 dramatically with increased soil depth. However, a highly constrained C:N:P ratio of

$392 \quad 134: 9: 1$ was found at the $0-10 \mathrm{~cm}$ organic-rich soil, which indicated reciprocal 
393 interactions between terrestrial organisms and the abiotic soil environment in the

394 biologically active soil layer. The C:P and N:P ratios in the soil were primarily

395 determined by soil P content, which was controlled by the soil (parent material) type,

396 soil weathering stage, and climate factors that affect soil weathering rate. Certainly, the

397 C:N:P ratios derived from this analysis based on China's soil database are very

398 different than those derived from other studies based on global soil datasets.

399 Consequently, our dataset and analysis provides valuable supplementary information

400 for the study of global soil elemental ratios, especially C:P and N:P ratios.

401

402 Acknowledgements This study was supported by NASA Interdisciplinary Science

403 Program (NNG04GM39C), NASA Land Cover and Land Use Change Program

404 (NNX08AL73G_S01), and the Chinese Academy of Science ODS Program. We

405 thank Dr. S. Wang for compiling the soil data sets, Dr. D. Johnson and two anonymous

406 reviewers for critical comments.

407 
408

409

410

411

412

413

414

415

416

417

418

419

420

421

422

423

424

425

427

426 Falkowski PG, Barber RT, Smetacek V (1998) Biogeochemical controls and feedbacks

428 Frizano J, Johnson AH, Vann DR, Scatena FN (2002) Soil phosphorus fractionation 429 during forest development on landslide scars in the Luquillo mountains, Puerto

\section{References}

Batjes NH (1996) Total carbon and nitrogen in the soils of the world. European Journal of Soil Science 47: 151-163

Batjes NH (2002) A homogenized soil profile data set for global and regional environmental research (WISE, version 1.1), Int. Soil Ref. and Inf. Cent., Wageningen, Netherlands, 2002/01. (www.isric.org)

Brady, NC, Weil RR (2002) The Nature and Properties of Soils. $13^{\text {th }}$ edition Pearson Education, Incorporation, New Jersey.Chadwick OA, Derry LA, Vitousek PM, Huebert BJ, Hedin LO (1999) Changing sources of nutrients during four million years of ecosystem development. Nature 397:491-497

Cleveland CC, Liptzin D (2007) C:N:P stoichiometry in soil: Is there a "Redfield ratio" for the microbial biomass? Biogeochemistry 85: 235-252.

Crews TE, Kitayama K, Fownes J, Herbert D, Mueller-Dombois D, Riley RH, Vitousek PM (1995) Changes in soil phosphorus and ecosystem dynamics across a long soil chronosequence in Hawai'i. Ecology 76: 1407-1424.

Elser JJ, Dobberfuhl D, MacKay NA, Schampel JH (1996) Organism size, life history, and N: P stoichiometry: towards a unified view of cellular and ecosystem

25 processes. BioScience 46: 674-684. 27 on ocean primary production. Science $281: 200-206$. 
$430 \quad$ Rico. Biotropica 34: 17-26.

431 Jenny H (1941) Factors of Soil Formation. McGraw-Hill, New York, USA.

432 Li Z, Zhao Q (2001) Organic carbon content and distribution in soils under different

433 land uses in tropical and subtropical China. Plant Soil 231: 175-185

434 McGonigle TP, Chambers ML, White GJ (2005) Enrichment over time of organic

435 carbon and available phosphorus in semiarid soil. Soil Science Society of America

436 Journal 69: 1617-1626.

437 McGroddy ME, Daufresne T, Hedin LO (2004) Scaling of C: N: P stoichiometry in

438 forests worldwide: implications of terrestrial Redfield-type ratios. Ecology 85:

$439 \quad 2390-2401$

440 Melillo, JM, Field CB, Moldan B (2003) Interactions of the Major Biogeochemical

441 Cycles: Global Change and Human Impacts. Scientific Committee on Problems of

442 the Environment (SCOPE) Series VOL 61. Island Press, Washington, USA.

443 National Soil Survey Office (1993, 1994a, 1994b, 1995a, 1995b, 1996, 1998) Soil

444 species of China, vol. I, II, III, IV, V, VI, VII, China Agriculture Press,

445 Beijing.Michaels AF (2003) The ratios of life. Science 300: 906-907.

446 Neff, J.C., S.E. Hobbie, and P.M. Vitousek. 2000. Nutrient and mineralogical controls

447 on dissolved organic C, N, and P fluxes and stoichiometry in Hawaiian soils.

$448 \quad$ Biogeochemistry 51: 283-302.

449 Neufeldt H, da Silva JE, Ayarza MA, Zech W (2000) Land-use effects on phosphorus

450 fractions in Cerrado Oxisols. Biology and Fertility of Soils 31: 30-37.

451 Oleksyn J, Reich PB, Zytkowiak R, Karolewski P, Tjoelker MG (2003) Nutrient 
452

conservation increases with latitude of origin in European Pinus sylvestris populations. Oecologia 136: 220-235.

Post WM, Emanuel WR, Zinke PJ, Stangenberger AG (1982) Soil Carbon Pools \& World Life Zones. Nature 298: 156-159

Post WM, Pastor J, Zinke PJ, Stangenberger G (1985) Global patterns of soil nitrogen storage. Nature 317: 613-616.

Reich PB, Oleksyn J (2004) Global patterns of plant leaf N and P in relation to temperature and latitude. Proceedings of the National Academy of Sciences USA 101: 11001-11006.

Redfield AC (1958) The biological control of chemical factors in the environment. American Scientist 46: 205-211.

Schimel DS (2003) All life is chemical. BioScience 53: 521-524.

Soil Survey Staff. 1975. Soil taxonomy. USDA, Washington DC, USA.

Sterner RW (1995) Elemental stoichiometry of species in ecosystems. In: Jones CG, Lawton JH (eds). Linking species and ecosystems. Chapman and Hall, New York, USA. p 240-252.

Sterner RW, Elser JJ (2002) Ecological stoichiometry: The biology of elements from molecules to the biosphere. Princeton University Press, Princeton, New Jersey.

Tian HQ, Melillo JM, Kicklighter DW, Pan S, Liu J, McGuire AD, Moore III B (2003) Regional carbon dynamics in monsoon Asia and its implications to the global carbon cycle. Global Planetary Change 37: 201- 217.

Tian HQ, Wang SQ, Liu JY, Pan S, Chen H, Zhang C, Shi XZ (2006) Storage and 
474 distribution of soil organic nitrogen in China. Global Biogeochemical Cycles 20:

$475 \quad$ GB1001, doi:10.1029/2005GB002464.

476 Vitousek PM, Hättenschwiler S, Olander L, Allison S (2002) Nitrogen and nature.

$477 \quad$ Ambio 31: 97-101.

478 Vitousek PM (2004) Nutrient Cycling and Limitation: Hawai'i as a Model System.

479 Princeton University Press, Princeton, New Jersey.

480 Vitousek PM, Walker LR, Whiteaker LD, Muellerdombois D, Matson PA (1987)

481 Biological Invasion by Myrica-Faya Alters Ecosystem Development in Hawaii.

$482 \quad$ Science 238: 802-804.

483 Walker TW, Syers JK (1976) The fate of P during pedogenesis. Geoderma 14: 1-19

484 Walker TW (1956) Nitrogen and herbage production. Proceedings, Seventh

$485 \quad$ International Grassland Congress 157.

486 Walker TW, Adams AFR (1958) Studies on soil organic matter. I. Soil Science 85:

$487 \quad 307-318$.

488 Wang S, Tian HQ, Liu J, Pan S (2003) Pattern and change in soil organic carbon

489 storage in China: 1960s-1980s. Tellus 55B: 416-427.

490 Wu C (1988) 1: 1000,000 Land Use Map of China. Science Press, Beijing, China.

491 Wu H, Guo Z, Peng C (2003) Distribution and storage of soil organic carbon in China.

$492 \quad$ Global Biogeochemical Cycles 17: 1048, doi:10.1029/2001GB001844.

493 Yang YH, Mohammat A, Feng JM, Zhou R, Fang JY (2007) Storage, patterns and

494 environmental controls of soil organic carbon in China. Biogeochemistry 84:

$495 \quad 131-141$. 
496 Zhang C, Tian HQ, Liu J, Wang S, Liu M, Pan S, Shi X (2005) Pools and Distributions

497 of Soil Phosphorus in China. Global Biogeochemical Cycles 19: GB1020,

$498 \quad$ doi:10.1029/2004GB002296.

499 Zinke PJ, Stangenberger AG, Post WM, Emanuel WR, Olson JS (1984) Worldwide

500 organic soil carbon and nitrogen data. ORNL/TM-8857. Oak Ridge National

$501 \quad$ Laboratory, Oak Ridge, Tennessee, U.S.A.

502 
TABLE 1. Climate zones in China and their corresponding annual average

$504 \quad$ climate data

\begin{tabular}{ccccc}
\hline Climate zones & $\begin{array}{c}\text { Minimum } \\
\text { temperature } \\
\left({ }^{0} \mathrm{C}\right)\end{array}$ & $\begin{array}{c}\text { Maximum } \\
\text { temperature } \\
\left({ }^{0} \mathrm{C}\right)\end{array}$ & $\begin{array}{c}\text { Mean annual } \\
\text { temperature } \\
\left({ }^{0} \mathrm{C}\right)\end{array}$ & $\begin{array}{c}\text { Mean annual } \\
\text { precipitation } \\
(\mathrm{mm})\end{array}$ \\
\hline Frigid highland & -7.3 & 0.7 & -3.4 & 348.5 \\
Temperate desert & -1.1 & 11.0 & 4.5 & 252.1 \\
Cool temperate zone & -3.7 & 7.9 & 1.7 & 418.2 \\
Warm temperate zone & 3.9 & 14.2 & 8.4 & 511.9 \\
Tropical \& subtropical & 11.8 & 19.5 & 15.0 & 1226.3 \\
zone & & & & \\
\hline
\end{tabular}

$505 *$ Data were calculated from the 30-year (1961-1990) average climate data in China. 
TABLE 2. Soil $\mathrm{C}, \mathbf{N}$ and $\mathbf{P}$ ratios in China

\begin{tabular}{|c|c|c|c|c|c|c|c|}
\hline & $\begin{array}{l}\text { Sample } \\
\text { number }\end{array}$ & $\mathrm{C}: \mathrm{N}$ & $\mathrm{C}: \mathrm{P}$ & $\mathrm{N}: \mathrm{P}$ & $C: A v \_P^{\circledR}$ & $\mathrm{N}: \mathrm{Av} \_\mathrm{P}$ & $\mathrm{C}: \mathrm{N}: \mathrm{P}$ \\
\hline $\begin{array}{l}\text { Organic-rich layer } \\
(0-10 \mathrm{~cm})\end{array}$ & $133^{\S}$ & $14.4 \pm 0.4 \mathrm{a}^{\xi}$ & $136 \pm 11 \mathrm{a}$ & $9.3 \pm 0.7 \mathrm{a}$ & $15810 \pm 1832 \mathrm{a}$ & $1114 \pm 115 \mathrm{a}$ & 134: 9: 1 \\
\hline $\begin{array}{c}\text { All soil layers } \\
\text { (Number-weighte } \\
\text { d) }\end{array}$ & $8125^{*}$ & $11.9 \pm 0.1 \mathrm{~b}$ & $61 \pm 0.9 b$ & $5.2 \pm 0.1 \mathrm{~b}$ & $64233 \pm 20414 b$ & $5725 \pm 1564 b$ & 60: 5: 1 \\
\hline $\begin{array}{l}\text { All soil layers } \\
\text { (Area-weighted) }\end{array}$ & $7731^{\#}$ & 12.1 & 61 & 5.0 & - & - & 60: $5: 1$ \\
\hline
\end{tabular}

${ }^{\circledR}$ Av_P: available P;

${ }^{\xi}$ Values were geometric means $\pm 1 \mathrm{SE}$; Different letters between two items in a column meant significantly different between them $(\mathrm{P}<0.05)$, while the same letters indicated no significant difference;

$\S$ The sample number for available P is only 85 ;

*The sample number for available $\mathrm{P}$ is 1,760 ;

${ }^{\#}$ No area information for 394 soil samples. 
TABLE 3. Total soil $C, N$ and $P$ concentrations and ratios along a gradient of soil

\begin{tabular}{ccccccc}
\multicolumn{7}{c}{ depth } \\
\hline $\begin{array}{l}\text { Depth } \\
(\mathrm{cm})\end{array}$ & $\mathrm{C}: \mathrm{N}$ & $\mathrm{C}: \mathrm{P}$ & $\mathrm{N}: \mathrm{P}$ & $\begin{array}{c}\text { Total C } \\
(\mathrm{mmol} / \mathrm{kg})\end{array}$ & $\begin{array}{c}\text { Total N } \\
(\mathrm{mmol} / \mathrm{kg})\end{array}$ & $\begin{array}{c}\text { Total P } \\
(\mathrm{mmol} / \mathrm{kg})\end{array}$ \\
\hline $0-10$ & $14.4 \pm 0.4 \mathrm{a}{ }^{\xi}$ & $136 \pm 11 \mathrm{a}$ & $9.3 \pm 0.7 \mathrm{a}$ & $2047 \pm 154 \mathrm{a}$ & $134 \pm 8.5 \mathrm{a}$ & $25 \pm 2.8 \mathrm{ab}$ \\
$10-50$ & $12.3 \pm 0.1 \mathrm{~b}$ & $74 \pm 1.3 \mathrm{~b}$ & $6.1 \pm 0.2 \mathrm{~b}$ & $1174 \pm 22 \mathrm{~b}$ & $96 \pm 2.5 \mathrm{~b}$ & $23 \pm 1.0 \mathrm{a}$ \\
$50-100$ & $11.2 \pm 0.1 \mathrm{c}$ & $46 \pm 1.4 \mathrm{c}$ & $4.2 \pm 0.1 \mathrm{c}$ & $617 \pm 26 \mathrm{c}$ & $53 \pm 1.5 \mathrm{c}$ & $19 \pm 0.5 \mathrm{~b}$ \\
$>100$ & $11.5 \pm 1.0 \mathrm{c}$ & $29 \pm 2.3 \mathrm{~d}$ & $2.7 \pm 0.1 \mathrm{~d}$ & $439 \pm 45 \mathrm{~d}$ & $38 \pm 1.8 \mathrm{~d}$ & $19 \pm 1.1 \mathrm{ab}$ \\
\hline
\end{tabular}

*Values were means $\pm 1 \mathrm{SE}$; different letters between two items in a column meant significantly different between them $(\mathrm{P}<0.05)$, while the same letters indicated no significant difference. 
TABLE 4. Soil $\mathrm{C}, \mathrm{N}$ and $\mathbf{P}$ concentrations and ratios in different climate zones in China

\begin{tabular}{cccccccc}
\hline Climate zone & Number & C: $\mathrm{N}$ & $\mathrm{C}: \mathrm{P}$ & $\mathrm{N}: \mathrm{P}$ & $\begin{array}{c}\text { C content } \\
(\mathrm{mmol} / \mathrm{kg})\end{array}$ & $\begin{array}{c}\mathrm{N} \text { content } \\
(\mathrm{mmol} / \mathrm{kg})\end{array}$ & $\begin{array}{c}\mathrm{P} \text { content } \\
(\mathrm{mmol} / \mathrm{kg})\end{array}$ \\
\hline Frigid highland & 749 & $13.6 \pm 1.1 \mathrm{a} *$ & $62 \pm 3.0 \mathrm{a}$ & $5.9 \pm 0.7 \mathrm{ac}$ & $1120 \pm 69 \mathrm{a}$ & $97 \pm 12 \mathrm{a}$ & $20.6 \pm 1.3 \mathrm{ab}$ \\
$\begin{array}{c}\text { Temperate desert } \\
\text { Cool temperate zone }\end{array}$ & 319 & $12.2 \pm 0.2 \mathrm{abc}$ & $32 \pm 2.1 \mathrm{~b}$ & $2.6 \pm 0.1 \mathrm{~b}$ & $775 \pm 63 \mathrm{~b}$ & $60 \pm 4 \mathrm{~b}$ & $26.0 \pm 2.6 \mathrm{~b}$ \\
$\begin{array}{c}\text { Warm temperate } \\
\text { zone }\end{array}$ & 1676 & $10.7 \pm 0.1 \mathrm{c}$ & $38 \pm 1.1 \mathrm{bd}$ & $3.6 \pm 0.1 \mathrm{~b}$ & $581 \pm 21 \mathrm{~b}$ & $53 \pm 2 \mathrm{~b}$ & $21.1 \pm 1.0 \mathrm{ab}$ \\
$\begin{array}{c}\text { Tropical \& } \\
\text { subtropical zone }\end{array}$ & 2071 & $12.1 \pm 0.1 \mathrm{~b}$ & $78 \pm 2.1 \mathrm{c}$ & $6.4 \pm 0.2 \mathrm{c}$ & $997 \pm 25 \mathrm{~d}$ & $79 \pm 2 \mathrm{~d}$ & $19.0 \pm 1.3 \mathrm{a}$ \\
Average & 5193 & $11.9 \pm 0.2$ & $60 \pm 1.1$ & $5.1 \pm 0.1$ & $927 \pm 20$ & $76 \pm 2$ & $20.9 \pm 0.7$ \\
\hline
\end{tabular}

*Values were means $\pm 1 \mathrm{SE}$; different letters between two items in a column meant significantly different between them $(\mathrm{P}<0.05)$, while the same letters indicated no significant difference. 
TABLE 5. The $\mathrm{C}, \mathrm{N}$ and $\mathrm{P}$ ratios for different soil orders

\begin{tabular}{ccccc}
\hline Soil order & $\begin{array}{c}\text { No. of } \\
\text { samples }\end{array}$ & C:N ratio & C:P ratio & N:P ratio \\
\hline Entisols & 2150 & $11.35 \pm 0.13 \mathrm{a} *$ & $56.4 \pm 1.6 \mathrm{ab}$ & $5.11 \pm 0.26 \mathrm{ab}$ \\
Histosols & 16 & $17.41 \pm 1.03 \mathrm{c}$ & $340 \pm 82 \mathrm{e}$ & $17.77 \pm 3.46 \mathrm{c}$ \\
Inceptisols & 727 & $11.41 \pm 0.19 \mathrm{a}$ & $57.6 \pm 3.2 \mathrm{ab}$ & $4.88 \pm 0.23 \mathrm{ab}$ \\
Andisols & 22 & $13.38 \pm 0.67 \mathrm{ac}$ & $42.2 \pm 7.9 \mathrm{acb}$ & $2.96 \pm 0.51 \mathrm{abde}$ \\
Aridisols & 300 & $11.24 \pm 0.22 \mathrm{a}$ & $29.0 \pm 1.8 \mathrm{c}$ & $2.60 \pm 0.15 \mathrm{~d}$ \\
Vertisols & 77 & $10.73 \pm 0.36 \mathrm{ab}$ & $41.7 \pm 4.4 \mathrm{ac}$ & $4.63 \pm 0.68 \mathrm{abde}$ \\
Alfisols & 614 & $12.1 \pm 0.24 \mathrm{abc}$ & $63.5 \pm 2.6 \mathrm{~b}$ & $5.46 \pm 0.29 \mathrm{abe}$ \\
Mollisols & 785 & $13.05 \pm 1.07 \mathrm{bc}$ & $59.8 \pm 2.9 \mathrm{ab}$ & $4.97 \pm 0.19 \mathrm{ab}$ \\
Ultisols & 502 & $13.32 \pm 0.26 \mathrm{bc}$ & $86.4 \pm 4.4 \mathrm{~d}$ & $6.43 \pm 0.28 \mathrm{e}$ \\
\hline
\end{tabular}

*Values were means $\pm 1 \mathrm{SE}$; different letters between two items in a column meant significantly different between them $(\mathrm{P}<0.05)$, while the same letters indicated no significant difference. 
TABLE 6. The $C, N$ and $P$ contents and $C, N$ and $P$ ratios for different soil weathering stages

\begin{tabular}{cccccccc}
\hline Weathering stage & No. of samples & C:N ratio & C:P ratio & N:P ratio & $\begin{array}{c}\text { C content } \\
(\mathrm{mmol} / \mathrm{kg})\end{array}$ & $\begin{array}{c}\text { N content } \\
(\mathrm{mmol} / \mathrm{kg})\end{array}$ & $\begin{array}{c}\text { P content } \\
(\mathrm{mmol} / \mathrm{kg})\end{array}$ \\
\hline Slight & 2915 & $11.37 \pm 0.11 \mathrm{a}^{*}$ & $64.9 \pm 1.7 \mathrm{a}$ & $5.78 \pm 0.23 \mathrm{a}$ & $803 \pm 19 \mathrm{a}$ & $71.0 \pm 3.2 \mathrm{a}$ & $18.7 \pm 1.0 \mathrm{a}$ \\
Moderate & 1776 & $12.32 \pm 0.48 \mathrm{~b}$ & $63.1 \pm 1.9 \mathrm{a}$ & $5.41 \pm 0.16 \mathrm{a}$ & $1004 \pm 36 \mathrm{~b}$ & $79.4 \pm 2.2 \mathrm{a}$ & $18.4 \pm 0.5 \mathrm{a}$ \\
Strong & 502 & $13.32 \pm 0.26 \mathrm{c}$ & $99.0 \pm 5.0 \mathrm{~b}$ & $7.37 \pm 0.32 \mathrm{c}$ & $994 \pm 46 \mathrm{ab}$ & $70.7 \pm 2.6 \mathrm{a}$ & $13.5 \pm 0.6 \mathrm{~b}$ \\
\hline
\end{tabular}

*Values were means $\pm 1 \mathrm{SE}$; different letters between two items in a column meant significantly different between them ( $\mathrm{P}<0.05)$, while the same letters indicated no significant difference.

TABLE 7. Comparisons of soil $\mathrm{C}$ : $\mathrm{N}$ ratios of different depths and soil orders around the world (Batjes 1996) and in China (this study)

\begin{tabular}{|c|c|c|c|c|c|c|c|c|}
\hline \multirow[b]{3}{*}{ Soil order } & \multicolumn{8}{|c|}{ Soil depth } \\
\hline & \multicolumn{2}{|c|}{$0-30 \mathrm{~cm}$} & \multicolumn{2}{|c|}{$30-50 \mathrm{~cm}$} & \multicolumn{2}{|c|}{$50-100 \mathrm{~cm}$} & \multicolumn{2}{|c|}{$0-100 \mathrm{~cm}$} \\
\hline & Batjes & This study & Batjes & This study & Batjes & This study & Batjes & This study \\
\hline Entisols & 14.21 & $12.05 \pm 0.42 *$ & 13.04 & $11.20 \pm 0.42$ & 12.03 & $10.87 \pm 0.43$ & 12.89 & $11.50 \pm 0.19$ \\
\hline Histosols & 30.10 & $16.33 \pm 4.17$ & 34.77 & $16.53 \pm 5.80$ & 26.02 & $18.81 \pm 2.84$ & 28.99 & $17.61 \pm 2.44$ \\
\hline Inceptisols & 13.42 & $12.36 \pm 0.48$ & 11.32 & $11.41 \pm 0.61$ & 10.50 & $10.66 \pm 0.85$ & 11.54 & $11.36 \pm 0.49$ \\
\hline Andisols & 15.52 & $13.10 \pm 2.00$ & 16.10 & $13.00 \pm 2.08$ & 16.68 & $12.79 \pm 2.74$ & 16.22 & $13.11 \pm 1.62$ \\
\hline Aridisols & 13.10 & $11.19 \pm 0.59$ & 11.46 & $10.89 \pm 0.90$ & 10.13 & $11.49 \pm 0.73$ & 11.28 & $11.56 \pm 0.46$ \\
\hline Vertisols & 15.52 & $10.54 \pm 1.54$ & 14.58 & $10.52 \pm 1.07$ & 14.58 & $11.54 \pm 1.23$ & 14.86 & $11.19 \pm 1.14$ \\
\hline Alfisols & 13.57 & $14.13 \pm 1.06$ & 11.56 & $12.57 \pm 0.72$ & 10.68 & $11.13 \pm 0.57$ & 11.73 & $12.39 \pm 0.60$ \\
\hline Mollisols & 13.01 & $12.10 \pm 0.37$ & 11.73 & $12.69 \pm 1.45$ & 10.47 & $11.69 \pm 0.48$ & 11.48 & $11.85 \pm 0.33$ \\
\hline Ultisols & 15.32 & $15.53 \pm 0.89$ & 11.74 & $12.71 \pm 0.84$ & 10.33 & $11.43 \pm 0.66$ & 12.11 & $12.83 \pm 0.86$ \\
\hline Average $^{\S}$ & 15.84 & 12.65 & 14.93 & 11.69 & 13.36 & 11.19 & 14.42 & 11.80 \\
\hline
\end{tabular}

$*$ Mean value $\pm 1.96 \mathrm{SE}(95 \%$ confidence interval)

${ }^{\S}$ This average is calculated from the number-weighted average (by soil profile numbers) of C: $\mathrm{N}$ ratios of all the soil orders. 
TABLE 8. The C, $N$ densities and C: $N$ ratios summarized from Post et al. (1985)*

\begin{tabular}{ccccc}
\hline Climate zones & No. of samples & $\begin{array}{c}\text { C density } \\
\left(\mathrm{kg} / \mathrm{m}^{3}\right)\end{array}$ & $\begin{array}{c}\mathrm{N} \text { density } \\
\left(\mathrm{kg} / \mathrm{m}^{3}\right)\end{array}$ & $\mathrm{C}: \mathrm{N}$ ratio \\
\hline $\begin{array}{c}\text { Tundra/ Frigid } \\
\text { highland }\end{array}$ & 53 & 22.73 & 1.37 & 20.3 \\
$\begin{array}{c}\text { Cool temperate zone } \\
\text { Warm temperate zone }\end{array}$ & 1613 & 14.60 & 0.92 & 20.2 \\
$\begin{array}{c}\text { Tropical and } \\
\text { subtropical zone }\end{array}$ & 546 & 13.00 & 1.16 & 20.6 \\
\hline
\end{tabular}

*All the data were summarized from the published results rather than calculated from original dataset. Each climate zone included all the land cover types showing in this zone, and the values of $\mathrm{C}$ and $\mathrm{N}$ density and $\mathrm{C}$ : $\mathrm{N}$ ratios were averaged by these land cover types. 
Table 9 Correlations among soil organic $\mathrm{C}(\mathrm{mmol} / \mathrm{kg})$, total $\mathrm{N}(\mathrm{mmol} / \mathrm{kg})$ and total $\mathrm{P}$ $(\mathrm{mmol} / \mathrm{kg})$ and among soil organic $\mathrm{C}$, total $\mathrm{N}$ and available $\mathrm{P}(\mathrm{mmol} / \mathrm{kg})$ for the organic-rich soil layer $(0-10 \mathrm{~cm})$ and the entire soil depth in China. Relatively well-constrained relationships $(\mathrm{P}<0.01)$ were found among soil total $\mathrm{C}, \mathrm{N}, \mathrm{P}$ and available $\mathrm{P}$ at the organic-rich soil layer, while no significant correlations were found for $\mathrm{C}: \mathrm{N}: \mathrm{P}$ ratios in the deeper soil.

\begin{tabular}{llcc}
\hline Independent variables & Dependent variables & $\begin{array}{c}\text { Sample } \\
\text { number }\end{array}$ & $\begin{array}{c}\text { Correlation } \\
\text { coefficient (R) }\end{array}$ \\
\hline Soil C at surface layer & Soil N at surface layer & 133 & 0.93 \\
Soil C at surface layer & Soil P at surface layer & 133 & 0.62 \\
Soil C at surface layer & Soil available P at surface layer & 85 & 0.69 \\
Soil N at surface layer & Soil P at surface layer & 133 & 0.51 \\
Soil N at surface layer & Soil available P at surface layer & 85 & 0.60 \\
Soil C for all layers & Soil N for all layers & 8125 & 0.88 \\
Soil C for all layers & Soil P for all layers & 8125 & 0.14 \\
Soil C for all layers & Soil available P for all layers & 1760 & 0.17 \\
Soil N for all layers & Soil P for all layers & 8125 & 0.14 \\
Soil N for all layers & Soil available P for all layers & 1760 & 0.17 \\
\hline
\end{tabular}

Note: The relationships between variables were significant $(\mathrm{P}<0.001)$ 


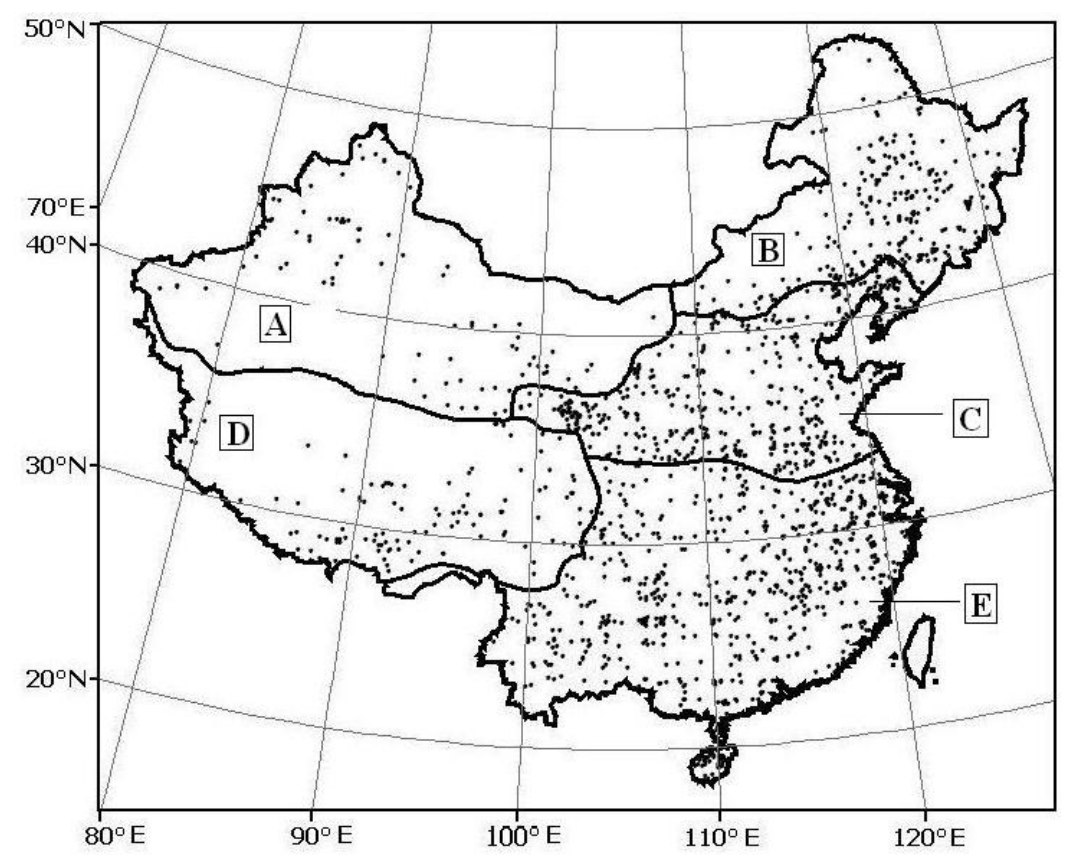

Fig. 1 Distribution of soil sampling points in China. Five zones were defined based on

climate differences: (A) temperate desert; (B) cool temperate zone; (C) warm temperate zone; (D) frigid highland; (E) tropical \& subtropical zone. 


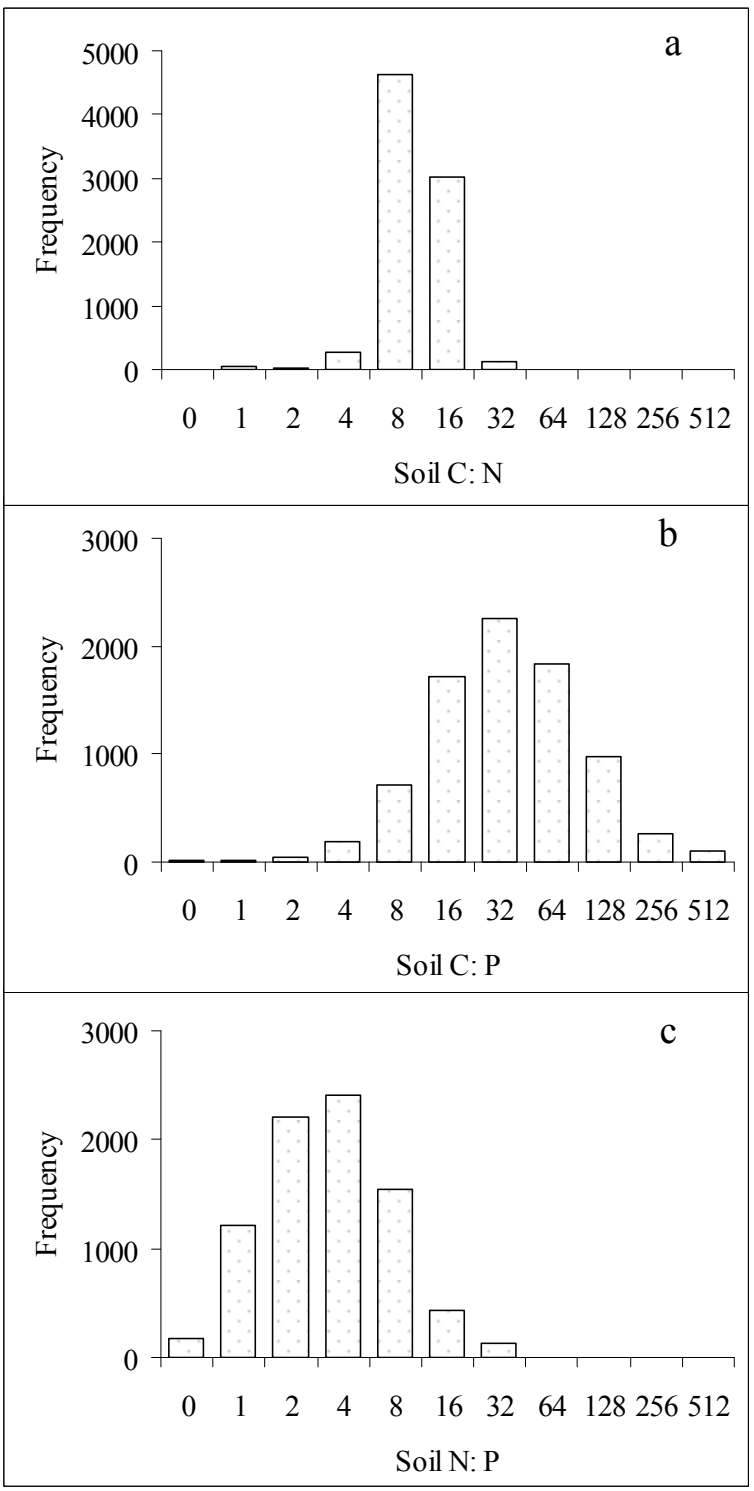

Fig. 2 Frequency distribution of soil C: N (a), C: P (b) and N: P (c) ratios in China. The $\mathrm{X}$-axis of the histogram is presented using a $\log 2$ scale to highlight the lognormal distribution. 

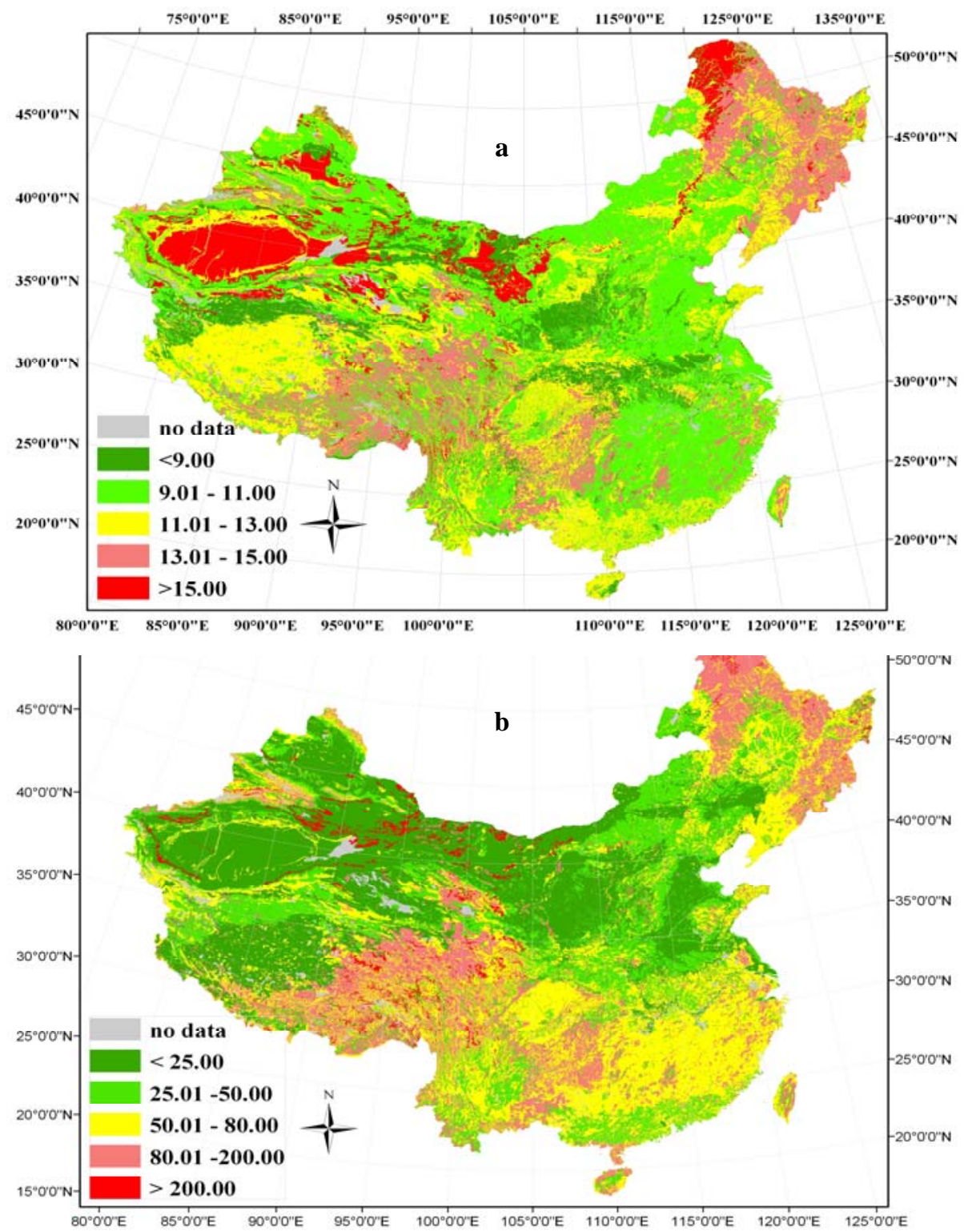


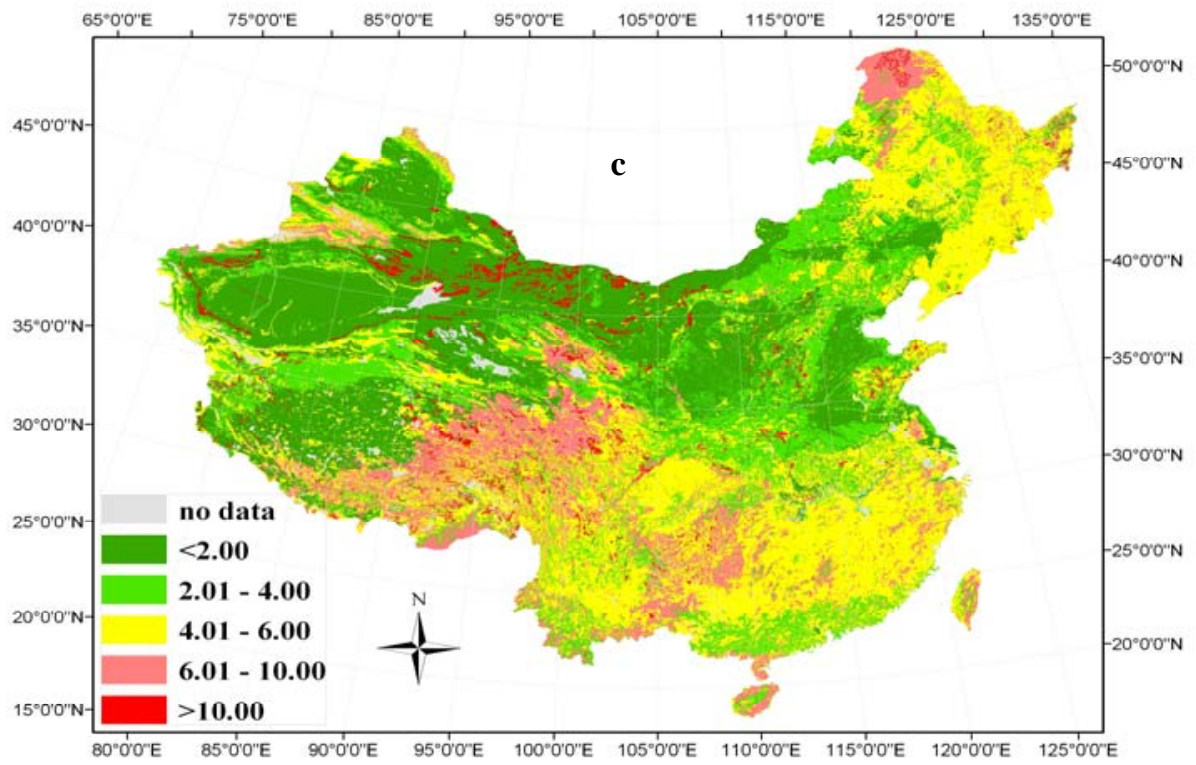

Fig. 3 Distribution of soil C: N, C: P and N: P ratios in China represented by C: N, C: $\mathrm{P}$ and $\mathrm{N}$ : $\mathrm{P}$ ratios of each soil sub-great group (a: C: $\mathrm{N}$ ratio; b: C: $\mathrm{P}$ ratio; $\mathrm{c}: \mathrm{N}: \mathrm{P}$ ratio). 